\title{
DOI: 10.17805/ggz.2018.6.4
}

\section{К. Марло в кино и на телевидении: основные тенденции рецепции*}

Б. Н. Гайдин

Московский гуманитарный университет

В статье представлена краткая история экранизаций произведений К. Марло. Охарактеризованы основные тенденщии, характерные для марловианских киноадаптаций, особенности рецепчии затрагиваемых драматургом тем в современных интерпретациях на экране ("Доктор Фауст» Р. Бертона и Н. Когхилла, 1967; «Эдуард II» Д. Джармена, 1991; и др.), а также приводятся примеры реакиии на них современного широкого зрителя и критиков. Рассматриваются воплощения образа самого писателя в работах современных кинорежиссеров и сиенаристов («Выжсивут только любовники» Дж. Джармуша, 2013; «Билл» Р. Брэйсуэлла, 2015).

Творчество К. Марло относительно редко привлекает современных деятелей киноиндустрии в отличие от наследия У. Шекспира, а вот его образ, напротив, достаточно часто присутствует в фильмах, повествующих обычно о жизни Шекспира и/или эксплуатирующих т. н. «шекспировский вопрос».

Ключевые слова: К. Марло; У. Шекспир; Марло в кино; Шекспир в кино; современный кинематограф; шекспиросфера

\section{Marlowe on Film and Television: Main Trends of Reception}

\author{
B. N. Gaydin
}

Moscow University for the Humanities

The article presents a brief history of film adaptations of Christopher Marlowe's works. The author seeks to analyze the main trends and features of the reception of the playwright's heritage in screen adaptations ("Dr. Faustus" by Richard Burton and Nevill Coghill, 1967; "Edward II” by Derek Jarman, 1991; etc.) as well as examples of contemporary viewers' and critics' reaction to them. The article dis-

\footnotetext{
* Статья подготовлена в рамках проекта «Кристофер Марло и его творчество в русской и мировой культуре: междисциплинарный взгляд» при финансовой поддержке Российского фонда фундаментальных исследований (грант № 18-012-00679).

The article was prepared within the framework of the project "Christopher Marlowe and His Literary Heritage in Russian and World Culture: An Interdisciplinary Look" with financial support from the Russian Foundation for Basic Research (grant No. 18-012-00679).
} 
cusses modern filmmakers and screenwriters' works where the English writer features as a character ("Only Lovers Left Alive” by Jim Jarmusch, 2013; “Bill” by Richard Bracewell, 2015).

Modern-day filmmakers are not so often attracted to C. Marlowe's works compared to the legacy of $W$. Shakespeare, but his image, on the contrary, is quite often presented in films that usually depict the life of Shakespeare and/or exploit the Shakespeare authorship question.

Keywords: C. Marlowe; W. Shakespeare; Marlowe on film; Shakespeare on film; contemporary cinematography; Shakespearean sphere

\section{ВВЕДЕНИЕ}

Число экранизаций произведений Кристофера Марло значительно меньше количества фильмов, так или иначе основанных на творческом наследии его современника Уильяма Шекспира. 19 июня 2018 г. в Internet Movie Database (IMDb) можно было найти всего 22 записи о Марло в качестве автора (Christopher Marlowe (a): Электронный ресурс) против без малого 1367 записей о Шекспире в этом же качестве (William Shakespeare: Электронный ресурс). Масштабы влияния Шекспира и Марло на кино и телевидение несопоставимы. Тем не менее, конечно, это не значит, что тема «Марло на экране» не заслуживает внимания.

\section{КРАТКАЯ ИСТОРИЯ ЭКРАНИЗАЦИЙ ПРОИЗВЕДЕНИЙ К. МАРЛО}

Если первая шекспировская экранизация относится к эпохе немого кино («Макбет», 1898; в роли Макбета - сэр Джонстон Форбс-Робертсон / Johnston Forbes-Robertson), то произведение К. Марло впервые было экранизировано уже в эпоху развития телевидения, почти на полвека позже. 22 июня 1947 г. в вечернем эфире Би-би-си был показан телефильм «Трагическая история доктора Фауста» (The Tragical History of Doctor Faustus). Продюсером фильма выступил Стивен Харрисон (Stephen Harrison), который адаптировал текст пьесы для телеэкранизации. Роль Фауста сыграл Дэвид Кинг-Вуд (David King-Wood), роль Мефистофеля - Хью Гриффит (Hugh Griffith) (The Tragical History of Doctor Faustus (a): Электронный ресурс). Трансляция велась в прямом эфире. K сожалению, нет данных о том, что запись трансляции сохранилась (Тhе Tragical History of Doctor Faustus (b): Электронный ресурс).

Такая же участь постигла и другую живую экранизацию С. Харрисона «Эдуард II», вышедшую в эфире английского телевидения 30 октября 1947 г. с Дэвидом Маркэмом (David Markham) в роли короля Эдуарда и Аланом Уитли (Alan Wheatley) в роли Пьера Гевестона, который позже получил известность 
как первый исполнитель роли Шерлока Холмса на телеэкране (Edward II (TV Movie 1947): Электронный ресурс; Edward II (а): Электронный ресурс).

Также в 1947 г. вышла музыкальная комедия «Телескоп» (Telescope) по сценарию Майкла Миллса (Michael Mills) (Telescope ... : Электронный ресурс). Однако найти информацию о том, каким образом фильм связан с творчеством Марло, нам не удалось.

В 1958 г. вышел получасовой телевизионный фильм «Трагическая история доктора Фауста» (The Tragical History of Doctor Faustus) режиссера Рональда Айра (Ronald Eyre). Текст Марло адаптировал сам режиссер, который, кстати, был не только крестным отцом известной актрисы Эммы Томпсон, но работал и над телефильмами по Шекспиру (сериал «Жизнь и смерть сэра Джона Фальстафа», 1959; «Как вам это понравится», 1963; «Фальстаф», 1982). Фильм также оказался для нас недоступен. Известно только, что текст пьесы был адаптирован для детей школьного возраста. Роль Фауста сыграл Уильям Сквайр (William Squire), а Мефистофеля - Джеймс Максвелл (James Maxwell) (The Tragical History of Doctor Faustus (TV Movie 1958): Электронный ресурс).

7 и 14 ноября 1961 г. на Би-би-си был показан телефильм «Доктор Фауст» в двух частях (Doctor Faustus (TV Series 1961-): Электронный ресурс), также адаптированный для школьников Р. Айром. Мефистофеля вновь сыграл Джеймс Максвелл (James Maxwell), а роль Фауста досталась на этот раз Алану Доби (Alan Dobie) - актеру, сыгравшему во многих шекспировских постановках. К сожалению, сложно говорить, насколько сильно отличалась эта версия от фильма 1958 г., поскольку в открытом доступе или на коммерческих площадках данные телефильмы найти нам не удалось.

22 марта 1964 г. на английском телевидении вышел очередной выпуск телешоу «О религии» (About Religion). Тема выпуска: «Взлет и падение героя: антология для Пасхальной недели» (The Rise and Fall of a Hero: An Anthology for Palm Sunday) (“About Religion” ...., Электронный ресурс). В нем наряду с сочинениями других британских писателей (У.Блейка, Дж. Оруэлла, Д. Томаса, О. Уальда и др.) звучали и произведения Марло.

В октябре 1966 г. состоялась премьера детективной драмы «Дело самоубийцы» (тж. «Смертельно опасное дело», «Смертельный роман»; The Deadly Affair) режиссера Сидни Люмета (Sidney Lumet). В основе сценария - роман Джона ле Kappe (John le Carré) «Звонок покойнику» (Call for the Dead, 1961; cм., например: Schwartz, 2011: Электронный ресурс). В фильме есть эпизод, в котором подозреваемая в шпионаже Эльза Феннан покупает два билета на постановку пьесы Марло «Эдуард II», где роли исполняли актеры Королевской шекспировской труппы под руководством сэра Питера Холла. В театре за Феннан ведется наблюдение, ведь именно там она встречается с другим агентом. Во время спектакля шпионы понимают, что им устроили западню. Эльза 
и Дитер смотрят спектакль и живо реагируют на происходящее на сцене. После финальной сцены, в которой убивают короля Эдуарда, Дитер незаметно душит Эльзу прямо во время аплодисментов. Чуть раньше действие фильма разворачивается на репетиции «Макбета» Шекспира: актеры играют знаменитую сцену с тремя ведьмами $(\mathrm{I}, 3)$. Можно предположить, что выбор именно этих пьес не случаен: шекспировский «Макбет» подчеркивает драматичность событий и тему убийства, а марловианский «Эдуард II» - темы борьбы за власть и шпионажа, связанные с ним мотивы лжи и предательства в финальной развязке. Заметим, что в романе «Звонок покойнику» также есть отсылка к постановке пьесы «Эдуард II» Марло, есть упоминание образа Леди Макбет и драмы «Герцогиня Амальфийская» («Трагедия герцогини Мальфи») другого современника Шекспира Джона Уэбстера героев (см.: Carré, 2002: 116, 75, 130). Карре использует “Marlow” / «Марло», однако имеется в виду топоним - место встречи героев (ibid: 140).

В 1967 г. на телеэкраны вышел эпизод сериала «Конфликт» (Conflict) под названием «Доктор Фауст» (Doctor Faustus). Режиссером адаптированной для школьников и студентов версии выступил Джордж Мор О’Ферролл (George More O’Ferrall). Роль Фауста сыграл Дэвид Берк (David Burke), Мефистофеля - Патрик Маги (Patrick Magee) (Conflict (TV Series 1966-1969): Электронный ресурс).

Однако первой лентой по произведению Марло, которая получила широкую известность, стал фильм «Доктор Фауст», снятый Ричардом Бертоном (Richard Burton) в сотрудничестве с Невиллом Когхиллом (Nevill Coghill), который также выступил в роли сценариста ${ }^{1}$. Знаменитый шекспировский актер, «наследник Лоуренса Оливье» Бертон сыграл главную роль. В роли Елены Троянской - Элизабет Тейлор (Elizabeth Taylor). В основе фильма - спектакль, который Когхилл поставил в 1966 г. в Драматическом обществе Оксфордского университета (Oxford University Dramatic Society). Фильм снимали в Риме в течение трех месяцев (Lindbergs, 2008: Электронный ресурс).

Картина получила в основном отрицательные отзывы кинокритиков. Они не пощадили ни Бертона, ни Тейлор: «Печальный пример университетской драмы в самом худшем виде» (“a sad example of university drama at its worst”) (Lewis, 1966: 49)². После выхода картины в прокате в США Рената Адлер (Renata Adler) сравнила ее с «домашним видео», снятым Бертоном и Тей-

\footnotetext{
${ }^{1}$ Отметим, что сценарий Н. Когхилла отличается от оригинала Марло, хотя в целом передает содержание пьесы. Режиссер также дополнил текст отрывками из «Мальтийского еврея», «Тамерлана» Марло и даже песней из пьесы «Игла матушки Гуртон» (Gammer Gurton's Needle), об авторстве которой у специалистов нет однозначного мнения. См.: Lindbergs, 2008: Электронный ресурс.

2 Здесь и далее перевод с английского наш. - Б. Г.
} 
лор для самих себя (Adler, 1968: Электронный ресурс). По ее мнению, авторы фильма стремились передать содержание пьесы настолько близко к тексту Марло, насколько это возможно сделать средствами кинематографа. Однако «или Ричард Бертон... желал, что понятно, сыграть какую-то другую роль, либо Невилл Когхилл... который адаптировал пьесу, очень хотел немного улучшить текст» (“But either Richard Burton, who plays Faustus, wished himself, understandably, in some other part, or Nevill Coghill, Merton Professor of English at Oxford, who adapted the play, was anxious to improve the text a little"; ibid). По ee мнению, в исполнении Бертона самые важные строки пьесы Марло звучат как шутки. Из актеров критик отметила лишь студента Оксфордского университета Андреаса Теубера (Andreas Teuber), сыгравшего роль Мефистофеля. Паулин Каэл (Pauline Kael) назвала игру Бертона «мертвым, приглушенным чтением» (“...Burton gives a dead, muffled reading”), а весь фильм - «скучнейшим эпизодом в серии картин о великих любовниках в истории, в которых снялись Бертон и Тейлор, начиная с “Клеопатры”» (“the dullest episode in the Burton and Taylor great-lovers-of-history series that started with CLEOPATRA”; Kael, 1990: 28). Наконец, Джудит Крист (Judith Crist) заметила, что фильм больше похож на «историю о мужчине, который продал свою душу за Элизабет Тейлор» (“It turns out to be the story of a man who sold his soul for Elizabeth Taylor”; цит. по: Halliwell, 1994: 303).

Тем не менее, на наш взгляд, не стоит недооценивать тот факт, что этот фильм помог привлечь внимание большого количества людей к творчеству К. Марло.

6 августа 1970 г. на Би-Би-Си была показана цветная телевизионная версия спектакля «Эдуард II» Prospect Theatre Company с молодым Иэйном МакКеленном (Ian McKellen) в главной роли. Режиссер: Тоби Роберстон (Toby Robertson), помощник режиссера: Ричард Маркуанд (Richard Marquand) Эта версия в основном получила хорошие отклики и вошла в историю, как первый британский телефильм, в котором демонстрировался поцелуй между мужчинами: королем Эдуардом II и Пьером Гевестоном, которого сыграл Джеймс Лоренсон (James Laurenson). Так, в журнале «Тайм» было отмечено следующее: авторы концепции телефильма не испугались показать, что пьеса написана «гомосексуалом о короле, который был гомосексуалом, действительно погубившим себя из-за безумной страсти» ("McKellen and Director Toby Robertson have confronted with stark candor the fact that Edward II is a play by a homosexual about a king who was a homosexual who indeed ruined himself for an infatuation”; The Stage Abroad ... , 1969: 187). В материале подчеркивалось, что телепостановка получилась «чувственной, неприятной, забавной, полной чувства вины и чрезвычайно мужской» ("It is sensuous, unpleasant, funny, guiltobsessed, and intensely masculine”; ibid). 
В мае 2003 г. И. Маккелен вспоминал, что «траектория развития Эдуарда такая же простая и мощная, как язык Марло. Он начинает как страдающий от безнадежной любви юнец. Его страсти сдерживаются его советниками, на которых он переносит свою злость и растущую силу. К моменту развязки пьесы он уже закоренелый тиран. Я подчеркивал все это старящим макияжем и накладной бородой» (“The arc of Edward's progression is as simple and strong as Marlowe's language. He starts as a lovelorn youth. His passions are thwarted by his advisers, on whom he turns his anger and growing strength. By the climax of the play he is a full-blown tyrant. I emphasised all this by ageing through make-up and false beard”; Edward II (b): Электронный ресурс; см. также: Bionic Jean's ... , 2016: Электронный ресурс). В работах исследователей можно найти мнение, что намеренный акцент на сексуальных мотивах (в том числе и с помощью эклектических костюмов, в которых частично были использованы и современные для конца 1960-х — начала 1970-х гг. элементы) был связан с желанием МакКеленна подчеркнуть разницу между образами Эдуарда II Марло и Ричарда II Шекспира, - ведь в это время он одновременно играл обе роли (см.: Aebischer, 2015). В 2009 г. телефильм был выпущен в формате DVD, что увеличило число тех, кто считает, что эта версия - одна из самых значительных интерпретаций пьес Марло в XX столетии (ibid: 316). Некоторые критики пишут, что современному зрителю достаточно сложно следить за развитием сюжета в оригинале Марло, вдобавок в этой телеверсии ощущается некоторый недостаток декораций, однако игра актеров помогает при желании разобраться и понять происходящее (см., например: Мау, 2016: Электронный ресурс).

9 ноября 1982 г. был выпущен франкоязычный телефильм «Эдуард II» режиссера Бернарда Собеля (Bernard Sobel), в котором роль короля исполнил Филипп Клевоно (Philippe Clévenot). Перевод выполнил Франсуа Рей (Françoise Rey).

В 1991 году пьеса К. Марло «Эдуард II» вновь была экранизирована. Свою версию представил Дерек Джарман (Derek Jarman) ${ }^{3}$, перенесший героев исторической хроники в XX век, хотя в некоторых эпизодах мы видим более традиционное изображение средневековья. Короля Эдуарда II сыграл Стивен Вэддингтон (Steven Waddington), Пьера Гевестона - Эндрю Тирнан (Andrew Tiernan), а королеву Изабеллу - Тильда Суинтон (Tilda Swinton). Основная тема фильма - гомоэротизм. Режиссер значительно переделал канву действия, чтобы подчеркнуть тему отношений между Эдуардом и Гевестоном (см.: Мау, 2016: Электронный ресурс). В отличие от Маккелена Джармуш был намного более радикальным гей-активистом, что, конечно, нашло отражение в его фильме. Так, в нем есть явная отсылка к протестам членов гей-сообщества,

${ }^{3}$ См. книгу режиссера фильма: Jarman, 1991. 
направленным против гомофобии и притеснения со стороны властей, например, к Стоунволлским бунтам 1969 г., а также более поздним акциям организации OutRage! и ее сторонников в начале 1990-х гг.; подробнее см.: Aebischer, 2015).

Работа Джармана получила хорошие отзывы критиков. Фильм выиграл несколько наград на престижных кинофестивалях ${ }^{4}$ и считается классикой нового «квир» кино (New Queer Cinema). К примеру, по мнению киноведа С. В. Кудрявцева, в «эстетской исторической драме» «все демонстративно перемешивается, словно режиссер снимает свою очередную футуристическую фантазию в духе ленты “На Англию прощальный взгляд”. И это ничуть не коробит, не возмущает, воспринимается как должное. Актуальность Марло не уступает злободневности Шекспира — и многие сюжетные повороты и даже отдельные фразы кажутся позаимствованными из сегодняшних газет, неважно: британских или российских. Искусство и действительность легко меняются местами в пространстве четырех столетий» (Кудрявцев, 2008; цит. по: Кудрявцев, 2007: Электронный ресурс). Критик подчеркнул, что Джармен, «знающий о близком смертельном исходе... творит свободно и празднично... Он являлся к нам в последние годы жизни именно с “ангельскими речами” (если воспользоваться названием кинопоэмы Дерека Джармена с сонетами Уильяма Шекспира, снятой еще в 1985 году) и будто из запредельного мира... Этот Джармен - бунтарь, который уже постиг мудрость бытия и инобытия» (там же). Джо Браун (Joe Brown) назвал фильм «стильной аскетичной адаптацией» (“stylishly austere adaptation”; Brown, 1992: Электронный ресурс), а Питер Траверс (Peter Travers) написал, что это «завораживающий фильм, который изобилует яростью, сексуальностью и радикальным остроумием» ("mesmerizing film that bristles with fury, sexuality and radical wit"; Travers, 1992: Электронный ресурс).

В 1994 г. вышел фильм чешского режиссера Яна Шванкмайера (Jan Švankmajer) «Урок Фауста» (Lekce Faust (Faust)), в котором роль Фауста сыграл Петр Чепек (Petr Čepek). В картине использованы различные вариации легенды о докторе Фаусте, в том числе предложенные Марло и Гёте. Кинолента была снята в Праге, содержит кроме натурных съемок также элементы кукольной и пластилиновой мультипликации. Художественная ткань фильма достаточно насыщенная и многослойная и требует отдельного рассмотрения.

\footnotetext{
${ }^{4}$ Т. Суинтон была награждена кубком Вольпи за лучшую женскую роль на 48-м Венецианском кинофестивале в 1991 г., а в 1992 г. Д. Джармен получил сразу три премии (Международной федерации кинопрессы - ФИПРЕССИ, специальную награду «Тедди» Берлинского международного кинофестиваля и «Золотой Хичкок» Британского кинофестиваля в Динарде).
} 
7 апреля 2003 г. вышла 12-я серия 50 сезона польского телепроекта «Телевизионный театр» (Teatr telewizji) под названием «Эдуард II». Режиссером телеспектакля выступил Мацей Прус (Maciej Prus), в роли Эдуарда II - Арто Жмиевский (Artur Zmijewski). Был использован перевод поэта Ежи С. Сито (Jerzy S. Sito).

24 октября 2012 г. была выпущена запись спектакля «Доктор Фауст» в театре «Глобус» режиссера Мэтью Данстер (Matthew Dunster). Роль доктора Фауста сыграл Пол Хилтон (Paul Hilton).

1 декабря 2012 г. вышел полнометражный музыкальный триллер «Призраки Фауста» (The Ghosts of Faust) режиссера Райана Тидрика (Ryan Tidrick), в котором частично был использован «Доктор Фауст» Марло. В роли Фауста - Эл Крэддок (Al Craddock).

В 2012 г. был представлен малобюджетный фильм «Мальтийский еврей» (The Jew of Malta) режиссера Дугласа Mopca (Douglas Morse), который также выступил автором адаптации пьесы Марло ${ }^{5}$. В своем интервью он указал, что решил экранизировать эту пьесу после просмотра одноименного спектакля режиссера Сета Дуерра (Seth Duerr), который тот поставил с актерами Йорской шекспировской труппы (York Shakespeare Company). Пьеса оказалась «забавной», «циничной» и «очень глубокой» (“It was funny; it was cynical, and it was, to me, very visceral”; Interview with Douglas Morse: Электронный ресурс). В роли «психопата и серийного убийцы» ("psychopath and a serial killer”; ibid) Вараввы в фильме снялся С. Дуерр. Дерек Смит (Derek Smith) сыграл роль правителя Мальты Фарнезе. Режиссер подбирал актеров с учетом их расовой и этнической принадлежности, пытаясь сделать «очень мультикультурный актерский ансамбль» (“а very multicultural cast”; ibid). К примеру, по задумке режиссера слова Макиавелли произносит итальянец на родном языке, Белламиру играет испанка, Пилью Борсо - чернокожий актер, монахинь и придворных - белокожие актеры. Поскольку фильм создавался во многом как образовательный проект, режиссер очень большое внимание уделял точной передаче текста, стараясь избежать каких-либо сокращений (Scott, 2013: 177). Отметим также мнение режиссера о том, что пьесу не стоит считать антисемитской, поскольку Марло придерживался атеистических взглядов. Он включил в пьесу множество христианских стереотипов о евреях, высмеивая эти заблуждения.

В 2016 г. режиссер Ричард Энтони Данфорд (Richard Anthony Dunford) снял экспериментальный короткометражный фильм «Коробка для сердца»

5 Он также выступил режиссером фильмов «Вызов обыкновенного человека» (Тhe Summoning of Everyman, 2007) по моралите XV столетия, «Венецианский купец» по одноименной пьесе Шекспира (2009). 
(Heartbox), в которой был использован текст стихотворения Марло «Страстный пастух - своей возлюбленной» (The Passionate Shepherd to His Love).

1 января 2018 г. вышел телефильм «Мальтийский еврей» режиссера Давида Cереро (David Serero), в которой он же сыграл роль Варравы. Количество актеров, участвовавших в съемках, позволяет предположить, что пьеса подверглась значительному сокращению (The Jew of Malta (TV Movie 2018): Электронный ресурс).

Большой интерес для нашего исследования также представляют работы кинорежиссеров и сценаристов, в которых использован образ К. Марло (например, «Влюбленный Шекспир» Джона Мэддена, 1998; «Аноним» Роланда Эммериха, 2011, «Выживут только любовники» Джима Джармуша, 2013; «Билл» Ричарда Брэйсуэлла, 2015; комедийный сериал «Уильям наш, Шекспира» Мэтта Липси и Ричарда Бодена, 2016; «Уилл» Крэйга Пирса, 2017). В данной статье мы рассмотрим два примера.

\section{«ВЫЖИВУТ ТОЛЬКО ЛЮБОВНИКИ» ДЖИМА ДЖАРМУША}

В 2013 г. на 66-м Каннском кинофестивале режиссер Джим Джармуш (Jim Jarmusch) представил фильм «Выживут только любовники» (Only Lovers Left Alive), в котором К. Марло сыграл сэр Джон Винсент Хёрт (John Vincent Hurt). Главные герои фильма - вампиры Адам (Том Хиддлстон / Tom Hiddleston) и Ева (Тильда Суинтон / Tilda Swinton). Лента, которую сам режиссер охарактеризовал как «криптовампирскую любовную историю» (“сrурtovampire love story”; Macnab, 2011: Электронный ресурс), получила в целом положительные отзывы кинокритиков. Например, она была признана лучшим фильмом 2014 года по версии интернет-журнала Cineticle (Дёшин: Электронный ресурс).

Если Адам - музыкант, скупающий редкие инструменты и живущий отшельником в доме-студии в Детройте (США), то Ева предпочитает Ближний Восток и Африку и не может жить без книг, запоем читая на разных языках. С собой в путешествие она собирает два чемодана книг («Любовь на луне» / Los amores en la luna Рамона де Кампоамора, «Дон Кихот» Мигеля де Сервантеса Сааведры, «Конец игры» / Endgame Сэмюэля Беккетта, «Путешествие и приключения капитана Гаттераса» Жюля Верна, «Превращение» Франца Кафки и др.).

К. Марло появляется в образе старика, передвигающегося на костылях, который доставляет Еве необходимую ей кровь от врача-француза. В фильме присутствуют отсылки и к другим реальным историческим лицам (например, к английскому композитору Уильяму Лоусу). Ева интересуется, как дела «у великолепного Кристофера Марло». Он отвечает, что много раз просил, чтобы его не называли так на людях. Ева парирует: «Ты - психопат! Я храню 
тайны, тебе ли не знать? Но я просила всего лишь устроить самый вкусный литературный скандал в истории». Марло: «Евочка, то было четыре века назад». Ева: «Ты носишь эту душегрейку четыре века». Марло: «Мне подарили ее в 1586 и это мой любимый наряд». Ева: «Хочешь сказать, мы никогда не выпустим кота из мешка? Может, хотя бы намекнем как-то? Разожжем волнующий хаос?» Марло: «По-моему, миру хватает хаоса, и больше пока ни к чему». Ева: «Вот зануда!». Ева берет «товар», целует Марло и уходит из кафе, оставляя один пакет Марло. Если сначала зрителю еще едва ли понятно, что за «литературный скандал» имеется в виду, то в конце фильма станет ясно, что речь идет о проблеме авторства произведений У. Шекспира и мнении ряда исследователей, что часть из них принадлежит перу Марло 6 .

В фильме есть и другие аллюзии на творчество Марло. Например, Адам приходит в больничную лабораторию, чтобы купить кровь, с бейджиком «доктор Фауст» и устаревшим стетоскопом. В фильме также присутствует отсылка к мифу о гомосексуальности драматурга. Марло и Ева встречаются на причале, он рассказывает ей, что ему приснилась ее «шабутная сестра» Ава. Старик задумывается и мысленно переносится «в Италию, на пару веков назад». Ева: «Он был красавчиком?»

Марло просит Еву быть осторожной, отмечает, что не понимает, почему она не живет вместе с «романтичным плутом» Адамом. Ева заявляет, что он только романтик, и вина в этом «Шелли, Байрона и тех французиков». Марло: «Жаль, что я не встретил его до того, как написал “Гамлета". Он стал бы идеальным прототипом главного героя». Ева также читает в самолете 116-й сонет Шекспира: "Love's not Time's fool, though rosy lips and cheeks..." (в русском дубляже был использован перевод Н. В. Гербеля - «Любовь в теченье лет не меркнет, не тускнеет...»).

Во время игры в шахматы Ева передает Адаму привет от его «кумира» К. Марло, к которому сама неравнодушна. На это он отвечает, что кумиров у него нет, и просит не отвлекать его от игры. По воспоминаниям Адама, Байрон был «напыщенным ослом», а Мэри Уолстонкрафт - «очень вкусной». На стене в доме Адама среди портретов композиторов, музыкантов, писателей и ученых весит и портрет Марло.

Ева находит пистолет Адама с пулей из самого твердого дерева, спрашивает его, зачем она ему. Она понимает, что у него есть суицидальные наклонности, наводит пистолет на себя, он запрещает ей так делать. Ева говорит Адаму о его эгоцентричности, которая является «растратой жизни». А ее «можно посвятить созерцанию, любованию природой, наслаждению добротой и дружбой и... танцам».

${ }^{6} \mathrm{O}$ «шекспировском вопросе» см., например: Иванов, Макаров, Радлов, 2018. 
Из Детройта Адам и Ева улетают в Марокко (Танжер). Интересно, что они отказываются лететь туда через Лондон. По приезду они не могут найти Марло, их силы на исходе, поскольку они лишились канала доставки свежей крови. Они находят ученика Марло, писателя Биляла, который рассказывает им, что его «учитель плох», а «ситуация очень серьезная». При встрече Марло говорит Еве: «Так-так, смотрите кого принесло. Хреново выглядишь». Ева: «Мой милый старик». Затем в фильме снова звучат строчки из Шекспира, на этот раз из «Гамлета». Марло: «О да, какое чудо природы человек». Адам: «А что мне эта квинтэссенция праха?» Марло рассказывает, что француза-доктора больше нет, и он выпил зараженной крови. Адам: «А ты все продолжал кропать, Кит». Марло: «Ну да, потихоньку, через века». Марло называет Биляла «прекрасным писателем», на это тот скромно отвечает, что «пока еще нет». Марло: «Скромностью сыт не будешь». Ева: «Да, вот доказательство». Она показывает на портрет Шекспира работы М. Друшаута, в который воткнут нож (см.: Долин, 2013: Электронный ресурс). Марло: «Необразованный зомбимещанин». Адам: «Игра стоила свеч, Кит. Тебя все же услышали». Марло: «Не было выбора. Все было ради политики. Все равно я должен быть мертв. И вот, наконец, я буду». Марло умирает, его друзья оплакивают его смерть.

Как отметил С. Дёшин, «Джармуш всегда мыслил себя против мейнстрима, не поперек, не параллельно, а именно против. Не в последнюю очередь против мейнстрима культурного. <...> И Шекспир - это тоже культурный мейнстрим. Тем более на фоне Кристофера Марло. Конечно, Джармуш и тут выбирает в первую очередь более маргинальную фигуру с вековой карты мировой литературы. Как и Тесла, подпольный гений альтернативной так и не случившейся истории науки, про которого Джармуш уже многие годы пытается поставить оперу. Его явно завораживают эти не случившиеся гении параллельной истории, что Тесла, что Марло» (Дёшин: Электронный ресурс). Сам Джармуш относит себя к числу антишекспиристов. В 2013 г. в Каннах он заявил: «Я думаю, что один из самых больших скандалов в истории литературы, который когда-нибудь может быть раскрыт, это то, что Уильям Шекспир ничего не писал. Нас, так называемых антистратфордианцев, много, мы не верим в это (авторство Шекспира. - Б. Г.). Среди нас Орсон Уэллс, Зигмунд Фрейд, Эмерсон, Джон Гилгуд... и теперь Джон Харт! Так что существуют различные теории о том, кто написал эти произведения, одна из них очень правдоподобна. Возможно, смерть Кристофера Марло была инсценирована» ("I think that one of the biggest scandals in literary history that some day may be divulged is that William Shakespeare didn't write anything. There are a lot of us, so-called antiStratfordians, who don't believe this. They included Orson Welles, Sigmund Freud, Emerson, John Gielgud... and now John Hurt! So there are different theories on 
who wrote these things, one of them is very possible. It is possible that Christopher Marlowe’s death was faked”; цит. по: Piazza, 2015: 270).

Таким образом, в фильме использован миф, согласно которому К. Марло не был убит в Дептфорде в 1593 г., а уехал из Англии и продолжил писать пьесы, которые затем публиковались под именем «Уильям Шекспир» (см., например: Степанов, Лезников, Кувшинова, 2014: Электронный ресурс). Отметим также, что имя уроженца Стратфорда-на-Эйвоне в фильме ни разу не звучит.

\section{«БИЛЛ» РИЧАРДА БРЭЙСУЭЛЛА}

18 сентября 2015 г. вышла кинокомедия под незамысловатым названием «Билл» (Bill), снятая режиссером Ричардом Брэйсуэллом (Richard Bracewell). Начало фильма отсылает зрителя к известным историческим событиям времен Англо-испанской войны (1585-1604). Испанский король Филипп II намерен вернуть на Альбион католицизм, но Непобедимая армада потоплена, благодаря, главным образом, «хорошей погоде». Елизавета посылает агентов на поиски испанского золота. Один из них, известный мореплаватель сэр Ричард Хоукинс (Richard Hawkins), был схвачен во дворце Филиппа. Уже здесь можно услышать «расширенную» шекспировскую цитату из уст самого короля Испании: "Well, well, well, well” (cp. слова Гамлета, обращенные Офелии: "I humbly thank you; well, well, well” (III, 1)).

В центре фильма - т. н. «потерянные годы» шекспировской биографии. Билл Шекспир (Мэтью Бэйнтон / Mathew Baynton) пробует себя в качестве лютниста в группе Mortal Coil («Смертный узел» - еще одна отсылка к словам из знаменитого монолога Гамлета «Быть или не быть»: "When we have shuffled off this mortal coil...”), однако без особого успеха, поскольку его подход к сольным партиям слишком «необычен» для публики. Участники группы выгоняют Билла из коллектива. Супруга предлагает мужу устроиться к мяснику. Но Шекспир уже написал отличную пьесу и решает отправиться в Лондон («Имя Шекспира будут помнить через 20 лет!»). Билл любит жену и детей, но его желание прославиться, видимо, намного сильнее. Шекспир уезжает завоевывать столицу, несмотря на скепсис Энн.

В фильме мы встречаем и Кита Марло в исполнении Джима Хоувика (Jim Howick). Шекспир знакомится с ним в трактире «Перо и рапира» (The Quill and Rapier). Марло сообщает, что театры закрыты, а он, самый успешный драматург Лондона, не может позволить себе купить дом. Затем Марло показывает Биллу объявление о вакансиях. Шекспир напишет жене, что его дела в Лондоне идут хорошо, но когда та приедет туда с детьми, то обнаружит мужа, работающим «зазывалой» в костюме помидора. Билл заявляет ей, что со временем может стать также успешен, как и «Крис» Марло, но оказывается, что и 
его друг вынужден зарабатывает на жизнь, ходя по улицам в образе огурца. Интересно, что в фильме Марло, получив угрозы от русских кредиторов лишить его жизни, решает выдать Шекспира за паписта, чтобы самому продать пьесу в Дептфорде. Но здесь он погибает, став жертвой шпионских интриг.

Образ Марло, известные факты его биографии, а также мифы о нем добавляют фильму глубины и исторической правдоподобности. Эпизоды, в которых сравниваются Марло и Шекспир, носят комический характер и придают ленте особый остроумный колорит. Фильм получил хорошие отзывы в прессе. К примеру, Марк Кермуд (Mark Kermode) отметил, что его создателям удалось найти баланс между исторически правдоподобными шутками и откровенным фарсом, что несомненно понравится и взрослым и детям (“Nicely balancing its historically literate gags with broad knockabout slapstick, Bill is a crowd-pleasing treat that should tickle audiences young and old alike”; Kermode, 2015: Электронный ресурс).

\section{ЗАКЛЮЧЕНИЕ}

Таким образом, можно констатировать, что хотя число экранизаций произведений К. Марло значительно меньше, чем количество фильмов по У. Шекспиру, тем не менее определенный интерес наследие Марло для кинематографистов и телевизионщиков все же представляет ${ }^{7}$. Образ Марло в кинематографе чаще всего неразрывно связан с Шекспиром. Даже если Шекспир не является действующим лицом (как, например, в фильме Джармуша), он все равно незримо «присутствует» в художественной ткани фильма.

В данный момент в базе IMDb можно найти сведения о задуманном фильме, посвященном Кристоферу Марло - экранизации пьесы Фрэнсиса Хэмита (Francis Hamit) «Марло: елизаветинская трагедия» (Marlowe: An Elizabethan Tragedy, 1988) (Christopher Marlowe (b): Электронный ресурс) ${ }^{8}$. По словам писателя, основная сюжетная линия будет повествовать о трагической судьбе Марло и его работе на секретную службу Ее Величества Елизаветы I (McNary, 2018: Электронный ресурс). В 2017 г. сценарий Хэмита стал победителем в номинации «Лучший исторический полнометражный сценарий» (Best Historical Feature Screenplay) на кинофестивале «Новый Ренессанс» (New Renaissance Film Festival) (NRFF London 2017 ... : Электронный ресурс). Станет ли эта работа первым повествующим о жизни Марло фильмом, в котором вообще не будет отсылок к Шекспиру, покажет время.

\footnotetext{
${ }^{7}$ Например, по данным IMDb, по произведениям другого современника Шекспира, его друга и соперника Б. Джонсона был снят всего один телеспектакль. См.: Ben Johnson: Электронный ресурс.

8 См. также видео, в котором Ф. Хэмит представляет идею фильма: https:// www.youtube.com/watch?v=P2ROtVlR-L8
} 


\section{СПИСОК ЛИТЕРАТУРЫ}

Дёшин, С. Быть Джимом Джармушем [Электронный ресурс] // Cineticle. URL: http://www.cineticle.com/texts/1175-jim-jarmusch.html [архивировано в WaybackMachine] (дата обращения: 19.09.2018).

Долин, А. (2013) Укусить, уснуть. «Выживут только любовники», режиссер Джим Джармуш [Электронный ресурс] // Искусство кино. № 7. URL: http://old.kinoart.ru/archive/2013/07/ukusit-usnut [архивировано в WaybackMachine] (дата обращения: 19.09.2018).

Иванов, Д. А., Макаров, В. С., Радлов, С. Д. (2018) Шекспир и «шекспиры» // Иностранная литература. № 8. С. 120-184.

Кудрявцев, С. В. (2007) «Эдвард II» (Edward II). Великобритания при участии Японии. 1991 [Электронный ресурс] // Kinanet. 15 августа. URL: https://kinanet.livejournal.com/1063715.html [архивировано в WaybackMachine] (дата обращения: 19.09.2018).

Кудрявцев, С. В. (2008) Эдвард II // 3500. Книга кинорецензий : в 2-х томах. М. : Печатный Двор. Т. 2: Н-Я. 736 с.

Степанов, В., Лезников, П., Кувшинова, М. (2014) Ночь. Улица. Вампир. Аптека [Электронный ресурс] // Сеанс : киноведческий журнал. 10 апреля. URL: https://seance.ru/blog/esse/inside_the_only_lovers/ [архивировано в WaybackMachine] (дата обращения: 19.09.2018).

"About Religion". The Rise and Fall of a Hero: An Anthology for Palm Sunday (TV episode 1964) [Электронный pecypc] // IMDb. URL: https://www.imdb.com/title/tt1837725/ [архивировано в WaybackMachine] (дата обращения: 19.09.2018).

Adler, R. (1968) Screen: Faustus sells his soul again: Burtons and Oxford do the devil's work [Электронный pecypc] // The New York Times. February 7. URL: https://www.nytimes.com/1968/02/07/archives/screen-faustus-sells-his-soulagainburtons-and-oxford-do-the-devils.html [архивировано в WaybackMachine] (дата обращения: 19.09.2018).

Aebischer, P. (2015) Marlowe in the movies // Christopher Marlowe in context / ed. by E. C. Bartels, E. Smith. Cambridge : Cambridge University Press. xxviii, 382 p. P. 316-324. 318. DOI: 10.1017/CBO9781139060882.034

Ben Johnson [Электронный pecypc] // IMDb. URL: https://www. imdb.com/name/nm5445351/ [архивировано в WaybackMachine] (дата обращения: 19.09.2018).

Bionic Jean's review of Edward II / B. Jean [Электронный ресурс] // Goodreads. 2016. April 26. URL: https://www.goodreads.com/review/show/ 1621181926 [архивировано в WaybackMachine] (дата обращения: 19.09.2018).

Brown, J. (1992) 'Edward II’ [Электронный pecypc] // Washington Post. April 10. URL: https://washingtonpost.com/wp-srv/style/longterm/movies/videos/ edwardiirbrown_a0adde.htm [архивировано в WaybackMachine] (дата обращения: 19.09.2018).

Carré, J. Le. (2002) Call for the dead. N. Y. : Pocket Books. xv, 144 p. 
Christopher Marlowe (a) [Электронный pecypc] // IMDb. URL: https://www.imdb.com/name/nm0549265/ [архивировано в WaybackMachine] (дата обращения: 19.06.2018).

Christopher Marlowe (b) [Электронный pecypc] // IMDb. URL: https://www.imdb.com/title/tt5093598/ [архивировано в WaybackMachine] (дата обращения: 19.09.2018).

Conflict (TV series 1966-1969) [Электронный ресурс] // IMDb. URL: https://www.imdb.com/title/tt3856212/ [архивировано в WaybackMachine] (дата обращения: 19.09.2018).

Doctor Faustus (TV series 1961-) [Электронный pecypc] // IMDb. URL: https://www.imdb.com/title/tt1589702/ [архивировано в WaybackMachine] (дата обращения: 19.09.2018).

Edward II (TV movie 1947) [Электронный ресурc] // IMDb. URL: https://www.imdb.com/title/tt3570716/ [архивировано в WaybackMachine] (дата обращения: 19.09.2018).

Edward II (а) [Электронный pecypc] // British Universities Film \& Video Council. URL: http://bufvc.ac.uk/screenplays/index.php/prog/1915 [архивировано в WaybackMachine] (дата обращения: 19.09.2018).

Edward II (b) [Электронный pecypc] // Sir Ian McKellen | Official Home Page. URL: http://www.mckellen.com/stage/edward/ [архивировано в WaybackMachine] (дата обращения: 19.09.2018).

Halliwell, L. (1994) Halliwell's film guide / ed. by J. Walker. N. Y. : HarperPerennial. x, $1347 \mathrm{p}$.

Interview with Douglas Morse / D. Morse, A. McCauley Basso [Электронный pecypc] // Marlowe in performance. URL: https://marloweinperformance. weebly.com/interview-with-douglas-morse.html [архивировано в WaybackMachine] (дата обращения: 19.09.2018).

Jarman, D. (1991) Queer Edward II. L. : British Film Institute. 169 p.

Kael, P. (1990) Dr. Faustus // The New Yorker. January 22. P. 28.

Kermode, M. (2015) Bill review - knockabout Horrible Histories fun with the Bard [Электронный pecypc] // The Guardian. 20 September. URL: https://www.theguardian.com/film/2015/sep/20/bill-review-horrible-histories-funshakespeare [архивировано в WaybackMachine] (дата обращения: 19.09.2018).

Lewis, A. (1966) Dr. Faustus gets cool a welcome: British reviewers criticize the Burtons and the play // The New York Times. 16 February. P. 49.

Lindbergs, K. (2008) Richard Burton’s Doctor Faustus (1967) [Электронный pecypc] // Cinebeats. February 29. URL: https://cinebeats.wordpress.com/ 2008/02/29/richard-burtons-doctor-faustus-1967/ [архивировано в WaybackMachine] (дата обращения: 19.09.2018).

Macnab, G. (2011) Swinton, Fassbender and Wasikowska line up for Jarmusch’s vampire story [Электронный pecypc] // Screen International. 16 May. URL: https://www.screendaily.com/news/production/swinton-fassbender-and-wasikowska-line-up-for-jarmuschs-vampire-story/5027597.article [архивировано в WaybackMachine] (дата обращения: 19.09.2018). 
May, M. (2016) British history in film | Edward II (1970) [Электронный pecypc] // Michael May: Writer of the graphic novel Kill All Monsters. Multifarious podcaster. August 16. URL: http://www.michaelmay.online/2016/08/british-historyin-film-edward-ii-1970.html [архивировано в WaybackMachine] (дата обращения: 19.09.2018).

McNary, D. (2018) Christopher Marlowe movie in the works from 'Star Wars' producer Gary Kurtz [Электронный pecypc] // Variety. May 30. URL: https://variety.com/2018/film/news/christopher-marlowe-movie-star-wars-producergary-kurtz-1202824874/ [архивировано в WaybackMachine] (дата обращения: 19.09.2018).

NRFF London 2017 - winners [Электронный ресурc] // New Renaissance Film Festival. URL: http://newrenaissancefilmfest.com/nrff-london-2017-winners [архивировано в WaybackMachine] (дата обращения: 19.09.2018).

Piazza, S. (2015) Jim Jarmusch: Music, words and noise. L. : Reaktion Books. $416 \mathrm{p}$.

Schwartz, D. (2011) Deadly Affair, The : “Top-notch spy thriller for the thinking man” [Электронный pecypc] // Movie reviews \& poetry by Dennis Schwartz. May 19. URL: http://homepages.sover.net/ ozus/deadlyaffair.htm [apxивировано в WaybackMachine] (дата обращения: 19.10.2018).

Scott, S. K. (2013) A survey of sources // The Jew of Malta: A critical reader / ed. by R. A. Logan. L. : Arden Shakespeare. xxxiv, 254 p. P. 169-190.

Telescope (TV movie 1947) [Электронный pecypc] // IMDb. URL: https://www.imdb.com/title/tt4365446/ [архивировано в WaybackMachine] (дата обращения: 19.09.2018).

The Jew of Malta (TV movie 2018) [Электронный ресурс] // IMDb. URL: https://www.imdb.com/title/tt7010146/ [архивировано в WaybackMachine] (дата обращения: 19.09.2018).

The stage abroad: A double crown (1969) // Time. September 19. Vol. 94. No. 12. P. 187.

The Tragical History of Doctor Faustus (TV movie 1958) [Электронный реcypc] // IMDb. URL: https://www.imdb.com/title/tt0817524/ [архивировано в WaybackMachine] (дата обращения: 19.09.2018).

The Tragical History of Doctor Faustus (а) [Электронный ресурс] // IMDb. URL: https://www.imdb.com/title/tt4327970/ [архивировано в WaybackMachine] (дата обращения: 19.09.2018).

The Tragical History of Doctor Faustus (b) [Электронный ресурс] // British Universities Film \& Video Council. URL: http://bufvc.ac.uk/screenplays/ index.php/prog/1759 [архивировано в WaybackMachine] (дата обращения: 19.09.2018).

Travers, P. (1992) Edward II [Электронный pecypc] // Rolling Stone. March 20. URL: https://www.rollingstone.com/movies/movie-reviews/edward-ii-101463/ [архивировано в WaybackMachine] (дата обращения: 19.09.2018). 
William Shakespeare [Электронный pecypc] // IMDb. URL: https:// www.imdb.com/name/nm0000636/ [архивировано в WaybackMachine] (дата обращения: 19.06.2018).

Дата поступления: 25.09.2018 2.

Гайдин Борис Николаевич - кандидат философских наук, начальник научно-исследовательского отдела цифровых технологий Института фундаментальных и прикладных исследований Московского гуманитарного университета, член-корреспондент Международной академии наук (IAS, Инсбрук). Адрес: 111395, Россия, г. Москва, ул. Юности, 5, корп. 6. Тел.: +7 (499) 37459-30. Эл. адрес: bngaydin@mosgu.ru

Gaydin Boris Nikolaevich, Candidate of Philosophy, Head of the Research Department of Digital Technologies, Institute of Fundamental and Applied Studies, Moscow University for the Humanities; Associate Member, International Academy of Science (IAS, Innsbruck). Postal address: Bldg. 6, 5 Yunosti St., Moscow, Russian Federation, 111395. Tel.: +7 (499) 374-59-30. E-mail: bngaydin@mosgu.ru

\section{Для ичитирования:}

Гайдин Б. Н. К. Марло в кино и на телевидении: основные тенденции рецепции [Электронный ресурс] // Горизонты гуманитарного знания. 2018. № 6. C. 44-60. URL: http://journals.mosgu.ru/ggz/article/view/892 (дата обращения: дд.мм.гггг). DOI: 10.17805/ggz.2018.6.4 